\title{
Can the Apparency Hypothesis explain the selection of medicinal plants in an area of caatinga vegetation? A chemical perspective
}

\author{
Nélson Leal Alencar ${ }^{1,3}$, Thiago Antonio de Sousa Araújo $^{1}$, Elba Lúcia Cavalcanti de Amorim² and \\ Ulysses Paulino de Albuquerque ${ }^{1}$
}

Received: March 24, 2009. Accepted: April 6, 2009

\begin{abstract}
RESUMO - (A Hipótese da Aparência explica a seleção de plantas medicinais em uma área de caatinga? Uma perspectiva química). Esta nota científica objetivou testar o poder da hipótese da aparência para explicar a seleção de plantas medicinais em uma comunidade rural assentada na Caatinga do Estado de Pernambuco. Foram estudadas 61 plantas, consideradas medicinais pelas pessoas, que passaram por uma triagem fitoquímica para atender as premissas da hipótese. Concluiu-se que a "aparência" não explica a totalidade dos achados reportados neste
\end{abstract} trabalho.

Palavras-chave: conhecimento botânico tradicional, etnobotânica, farmacopéias tradicional, fitoquímica

ABSTRACT - (Can the Apparency Hypothesis explain the selection of medicinal plants in an area of caatinga vegetation? A chemical perspective). This scientific note examines the ability of the apparency hypothesis to explain the selection of medicinal plants by members of a rural community located in the Caatinga dryland region of Pernambuco state. A total of 61 plants considered to be medicinal were examined phytochemically to test the premises of this hypothesis. It was concluded that apparency does not completely explain our findings. Key words: ethnobotany, phytochemistry, traditional botanical knowledge, traditional pharmacopeia

\section{Introduction}

A number of different theories have been developed to explain the criteria used by traditional communities to select medicinal plants, including those linked to anti-herbivory strategies such as the apparency hypothesis (for a review see Albuquerque \& Lucena 2005). The apparency hypothesis was originally suggested, in a human context, by Stepp \& Moerman (2001) to explain the predominance of herbs and weeds in traditional pharmacopoeias throughout the world and was first formally tested in the field of ethnobotany by Almeida et al. (2005).

The apparency hypothesis divides plants into "apparent" and "non-apparent" plants. According to this hypothesis "apparent" plants, such the shrubs and trees, tend to produce high molecular weight organic compounds with low toxicity that act as inhibitors of herbivore digestion ("quantitative defenses"); "non-apparent" plants (herbs, for example), on the other hand, produce low molecular weight organic compounds that are strongly bioactive and highly toxic ("qualitative defenses") (Feeny 1976; Albuquerque \& Lucena 2005). A detailed description of this hypothesis can be seen in Albuquerque \& Lucena (2005) and Albuquerque (2006).

This hypothesis therefore assumes that herbaceous plants generally contain compounds that are more bioactive than those encountered in shrub or arboreal species, and the plants selected as being medicinal by any given community should follow this trend (Albuquerque \& Lucena 2005). If the apparency hypothesis could explain the selection of medicinal plants by a rural community in an area of caatinga vegetation in Pernambuco state, Brazil, we would expected to find that the herbs used by these people would have higher frequencies of compounds associated with the "qualitative" defenses as opposed to the "quantitative" defenses of arboreal plants. The data analyzed here was collected during a study of the inclusion criteria used for medicinal plants found in a local pharmacopoeia, as examined from a chemical-ecological perspective (N.L Alencar and collaborators, unpublished data).

\section{Materials and methods}

Ethnobotanical data was collected in the Carão community, located $16 \mathrm{~km}$ from the center of the municipality of Altinho in northeastern Brazil, in an area of Caatinga dryland vegetation of Pernambuco state, Brazil. This municipality has 21,496 inhabitants, of which 10,542 reside in urban areas and 11,589 in rural environments (IBGE 2009). The ethnobotanical research involved 101 people between the ages of 19 and 83 in the Carão community (36 men and 65 women), accounting for $90.2 \%$ of the population there older than 18 . Details concerning the ethical and legal aspects of the data collection as well as the methodological approaches used can be found in Araújo et al. (2008). The basic procedures described below were applied to a data base that was used in the analyses of a number of different hypotheses (N.L Alencar and collaborators, unpublished data).

The original ethnobotanical survey recorded a total of 190 species used locally for medicinal purposes, but we chose to study only plants that were cited by at least three people during the interviews -in order to represent a way of use consensus (see Araújo et al. 2008) - resulting in a sample of 98 species. Additionally, the ready availability of these plants in this highly seasonal region was also considered, so that the final sampling included 61 plants.

The plants were collected between June and August 2007 and were subjected to phytochemical screening. Only the plant parts used locally to prepare the folk remedies were examined. The material was dried

\footnotetext{
1 Universidade Federal Rural de Pernambuco, Departamento de Biologia, Área de Botânica, Recife, PE, Brazil

2 Universidade Federal de Pernambuco, Centro de Ciências da Saúde, Departamento de Ciências Farmacêuticas, Recife, PE, Brazil

3 Corresponding author: nelsonalencar@ hotmail.com
} 
at room temperature and subjected to methanol extraction $(1 \mathrm{gm} / 10 \mathrm{ml})$. The following classes of compounds were investigated: phenols, tannins, terpenes (mono, di, tri, and sesquiterpenes), alkaloids, quinines (anthraquinones and naphthoquinones), and flavonoids. Thin layer chromatography (TLC) was used in these analyses according to the methodologies described by Wagner \& Bladt (1996) and Harbone (1998). These classes of compounds were selected in the present study because they represent two basic categories of bioactive organic compounds found in plants (see Feeny 1976): "quantitative" compounds (including tannins, phenols, flavonoids, and terpenes) of high molecular weight and low toxicity that basically act by reducing the digestibility of plant matter; and "qualitative" compounds (including alkaloids, triterpenes, naphthoquinones, and anthraquinones) having low molecular weights, high toxicity, and strong biological activities.

The Williams G Test was used to examine the relationship between plant habits and the percentage of positive occurrences for each class of compounds.

\section{Results and discussion}

Of the 61 plants selected, 24 species were considered trees $(39.34 \%)$, nine species were shrubs (14.75\%), and 28 species were classified as herbs (45.90\%). Details concerning the plants evaluated and the results of the phytochemical screening will be available in another paper. Tannins were found predominantly in trees, and more triterpenes were seen in herbs, our results did not support the apparency hypothesis as a whole. The herbs demonstrated higher frequencies of triterpenes than seen in arboreal $(\mathrm{G}=6.54$; $\mathrm{p}<0.05)$ or shrub $(\mathrm{G}=4.69 ; \mathrm{p}<0.05)$ species, although no significant differences were noted in terms of the other compounds assayed (Tab. 1). The rejection of the apparency hypothesis is justified by the fact that alkaloids were more common in trees $(\mathrm{G}=8.14 ; \mathrm{p}<0.01)$ while the apparency hypothesis predicted that more of these compounds would be expected in herbs. Additionally, no significant differences were observed in terms of the other compounds assayed (phenols, terpenes, and quinones) among these two plant habits. This data confirms the observations of Almeida et al. (2005) who reported that native caatinga trees contained alkaloids not detected in native herbs. Almeida et al. (2005) likewise concluded that the apparency hypothesis could not explain the selection of medicinal plants in other caatinga areas in northeastern Brazil.

This scientific note presents another example of the fact that the apparency hypothesis does not represent the best explanation for the selection of medicinal plants by rural communities, at least in Caatinga regions of northeastern Brazil.

Table 1. Percentage of positive occurrences of chemical compounds in trees, shrubs and herbs during the phytochemical screening of medicinal plants collected in Carão, Altinho, Pernambuco State, Brazil.

\begin{tabular}{|c|c|c|c|c|c|c|c|c|c|}
\hline & Habit & Phenols & Tannin & Flavonoid & Terpenoid & Triterpene & Naftoquinone & Antraquinone & Alkaloid \\
\hline 1 & $\begin{array}{c}\text { Trees } \\
\text { (24 spp.) }\end{array}$ & 87.50 & 91.67 & 58.33 & 70.83 & 41.67 & 4.17 & 70.83 & 50.00 \\
\hline 2 & $\begin{array}{l}\text { Shrubs } \\
\text { (9 spp.) }\end{array}$ & 88.89 & 88.89 & 66.67 & 77.78 & 44.44 & 0.00 & 77.78 & 66.67 \\
\hline 3 & $\begin{array}{c}\text { Herbs } \\
\text { (28 spp.) }\end{array}$ & 82.14 & 75.00 & 50.00 & 75.00 & 60.71 & 0.00 & 60.71 & 28.57 \\
\hline G test: $p$ value & $\begin{array}{c}G \text { test }(1 \times 3): G \\
(p) \\
G \text { test }(2 \times 3): G \\
(p)\end{array}$ & $\begin{array}{c}0.740 \\
(0.389) \\
5.556 \\
(0.0184)\end{array}$ & $\begin{array}{c}9.141 \\
(0.0025) \\
5.719 \\
(0.0168)\end{array}$ & $\begin{array}{c}1.083 \\
(0.298) \\
5.075 \\
(0.0243)\end{array}$ & $\begin{array}{c}0.254 \\
(0.6139) \\
0.0879 \\
(0.767)\end{array}$ & $\begin{array}{c}6.548 \\
(0.0105) \\
4.694 \\
(0.0303)\end{array}$ & $\begin{array}{l}- \\
-\end{array}$ & $\begin{array}{c}1.851 \\
(0.1736) \\
6.1165 \\
(0.0134)\end{array}$ & $\begin{array}{c}8.149 \\
(0.0043) \\
28.269 \\
(0.0001)\end{array}$ \\
\hline
\end{tabular}

(-): Unable to complete the test due to zero values.

\section{Acknowledgements}

The authors would like to thank the community of Carão for their gracious welcome and receptivity, as well as the following researchers from the Laboratory of Applied Ethnobotany (LEA) for their support during the ethnobotanical surveys: Ernani Machado de Freitas Lins Neto, Flávia Santos Almeida, Joabe Gomes de Melo, Alyson Luiz de Almeida, Miguel de Santana Almeida, Luciana Gomes de Sousa, Viviany Teixeira do Nascimento, and Lucilene Lima dos Santos. We also thank Victoria Lacerda of the Universidade Federal de Santa Catarina for help during her internship at the LEA; the Municipality of Altinho for logistic support, especially the Secretary of Agriculture Sr. Miguel Andrade Júnior; the Carão Community Health Agents; as well as CNPq for financial support ("Edital Universal") and for the productivity grant awarded to Ulysses Paulino de Albuquerque.

\section{References}

Albuquerque, U.P. 2006. Re-examining hypotheses concerning the use and knowledge of medicinal plants: a study in the Caatinga vegetation of NE Brazil. Journal of Ethnobiology and Ethnomedicine 2: 30 .
Albuquerque, U.P. \& Lucena, R.F.P. 2005. Can apparency affect the use of plants by local people in tropical forests? Interciencia 30: $506-510$.

Almeida, C.F.C.B.R.; Lima e Silva, T.C.; Amorim, E.L.C.; Maia, M.B.S. \& Albuquerque, U.P. 2005. Life strategy and chemical composition as predictors of the selection of medicinal plants from the caatinga (Northeast Brazil). Journal of Arid Environments 62: 127-142.

Araújo, T.A.S.; Alencar, N.L.; Amorim, E.L.C. \& Albuquerque, U.P. 2008. A new approach to study medicinal plants with tannins and flavonoids contents from the local knowledge. Journal of Ethnopharmacology 120: 72-80.

Feeny, P.P. 1976. Plant apparency and chemical defense. Pp. 1-40. In: J.W. Wallace \& R.L. Mansell (eds.). Recent Advances in Phytochemistry. New York, Plenum Press.

Harbone, J.B. 1998. Phytochemical methods. Dordrecht, Kluwer Academic Publishers.

IBGE - Instituto Brasileiro de Geografia e Estatística. http:// www.ibge.gov.br/ (consulted on march 2009).

Stepp, J.R. \& Moerman, D.E. 2001. The importance of weeds in ethnopharmacology. Journal of Ethnopharmacology 75: 25-31.

Wagner, H. \& Bladt, S. 1996. Plant Drug Analysis - A Thin Layer Chromatography Atlas. $2^{\text {nd }}$ ed. Berlin, Springer.

Versão eletrônica do artigo em www.scielo.br/abb e http://www.botanica.org.br/acta/ojs 